\title{
Hydrothermal vent shrimps display low expression of the heat-inducible hsp70 gene in nature
}

\author{
Juliette Ravaux ${ }^{1, *}$, Delphine Cottin ${ }^{1}$, Thomas Chertemps ${ }^{2}$, Gérard Hamel ${ }^{1}$, \\ Bruce Shillito $^{1}$
}

\begin{abstract}
${ }^{1}$ Université Pierre et Marie Curie - Paris 06 (UPMC), UMR 7138, Equipe Adaptations aux Milieux Extrêmes, and ${ }^{2}$ UPMC UMR-A 1272, Physiologie de l'insecte: signalisation et communication, 7 Quai St-Bernard, 75005 Paris, France
\end{abstract}

\begin{abstract}
The shrimp Rimicaris exoculata swarms over high-temperature chimneys at MidAtlantic Ridge hydrothermal sites, thriving in a mixture of hot vent fluid $\left(350^{\circ} \mathrm{C}\right)$ and cold seawater $\left(2^{\circ} \mathrm{C}\right)$. It may, therefore, be subjected to a thermal regime that is assumed to be stressful for animals. Evaluating the stress status of species in their natural environment is a key issue for understanding the thermal biology of metazoans. In the case of deep-sea species, attempts to quantify natural levels of stress proteins are obviously impaired by deleterious decompression effects during sampling. Here we quantified the heat shock protein ( $h$ sp70) mRNA expression of shrimps sampled at a depth of $2300 \mathrm{~m}$ and recovered at their native pressure. These shrimps were not heat-stressed, as witnessed by their very low level of heat-inducible $h s p 70$, while an important response was evidenced after an experimental $30^{\circ} \mathrm{C}$ exposure. Our data also indicate that $R$. exoculata was nevertheless attracted by the temperature of fluid emission, and would deal with the harsh thermal conditions through microhabitat selection close to its thermal preferendum $\left(10\right.$ to $\left.25^{\circ} \mathrm{C}\right)$.
\end{abstract}

KEY WORDS: Hydrothermal vents ' Rimicaris exoculata ' Thermal biology $\cdot$ Thermal stress $\cdot h s p 70$. Heat shock protein

Resale or republication not permitted without written consent of the publisher

\section{INTRODUCTION}

The thermal preference and tolerance of deep-sea hydrothermal fauna has been debated for years, especially for species colonising black smoker chimney walls (Cary et al. 1998, Chevaldonné et al. 2000). The tolerance of these species to high temperatures has mainly been inferred from in situ temperature measurements, while thermal biology studies using experimental designs are still in their infancy (Van Dover \& Lutz 2004). The shrimp Rimicaris exoculata, the emblematic species for the Atlantic vents, forms swarms of thousands of individuals on smoker walls. Because of the proximity of hot water venting, this shrimp lives in a highly fluctuating environment where temperatures $\left(2\right.$ to $40^{\circ} \mathrm{C}$ in the swarms; reviewed by Schmidt et al. 2008) can exceed its critical maximal temperature (33 to $37^{\circ} \mathrm{C}$; Ravaux et al. 2003). This spe- cies may thus be exposed to acute thermal variations that are assumed to be stressful. Here we report the first assessment of natural levels of stress gene expression in vent shrimps.

Providing methods that reliably witness natural stress conditions is a great challenge in deep-sea vent studies. A major issue is the collection trauma: following recovery at depths greater than $2000 \mathrm{~m}$, the physiological state of shrimps is far from being comparable to that in situ, as witnessed by the unnatural behaviour observed upon recovery (a few erratic movements and loss of balance, excluding long-term rearing at atmospheric pressure; Shillito et al. 2008). Here we provide significant progress in addressing this question by recovering animals at their native pressure, from a depth of $2300 \mathrm{~m}$. These specimens were further tested for their stress-inducible hsp 70 gene expression, which besides being a good metric for estimating the physio- 
logical effects of thermal variations, also reflects the thermal history of the organisms (Feder \& Hofmann 1999). For a comparison with these natural levels of stress gene expression, we quantified in parallel the hsp70 expression in shrimps subjected to temperature shocks at the boundaries of bearable environmental temperatures $\left(2^{\circ} \mathrm{C}\right.$ and $\left.30^{\circ} \mathrm{C}\right)$.

\section{MATERIALS AND METHODS}

Animal collection and experimentation. Rimicaris exoculata were collected from the Rainbow vent site (Mid-Atlantic Ridge, 36 $14^{\prime} \mathrm{N}, 2300 \mathrm{~m}$ depth), using the suction device of the DSV 'Nautile' submersible ('Momardream' 2007 cruise). During 2 different dives, 61 shrimps were collected at 2 distinct spots around the main chimney of the site, and recovered at their native pressure by using the PERISCOP system (Shillito et al. 2008), composed of an in situ sampling cell and an isobaric recovery device. Autonomous recorders provided temperature and pressure history during sample recovery (Fig. 1A). Pressure remained within 98 to $103 \%$ of in situ pressure $(23.5 \mathrm{MPa})$ throughout the sampling process. More shrimps were sampled without the isobaric sampler, and the temperature in the sampling cells of the submersible suction device ranged from 15 to $20^{\circ} \mathrm{C}$ upon their recovery on the ship deck. These shrimps were either frozen in liquid nitrogen or transferred into 201 aquaria (IPOCAMP,
Fig. 2A) operated at in situ pressure, in flow-through mode $\left(20 \mathrm{l} \mathrm{h}^{-1}\right.$ flow rate), during $\sim 10 \mathrm{~h}$, in order to carry out 3 experiments (Fig. 1B): maintenance at $10^{\circ} \mathrm{C}$ constant temperature ( $\mathrm{n}=48$ ind.), or $10^{\circ} \mathrm{C}$ except for $1 \mathrm{~h}$ exposure at $30^{\circ} \mathrm{C}\left(\mathrm{n}=42\right.$ ind.) or at $2^{\circ} \mathrm{C}(\mathrm{n}=30 \mathrm{ind}$.). All samples were frozen in liquid nitrogen when experiments ended. The survival rate was $100 \%$ for animals collected using PERISCOP, and within 88 to $93 \%$ for experimental individuals.

RNA extraction. Total RNA was extracted from ground abdomens using Trizol reagent (Invitrogen) in accordance with the manufacturer's protocol. RNA $(4 \mu \mathrm{g})$ was treated to remove DNA contamination by using the Turbo-DNAse kit (Ambion), and then reversely transcribed to cDNA with the oligo $(\mathrm{dT})_{18}$ primer and Superscript II reverse transcriptase kit (Invitrogen) according to the manufacturer's instructions.

Real-time quantitative RT-PCR. The qPCR analyses were conducted on shrimps recovered at their native pressure during 2 different dives ( $\mathrm{S}$ for Dive 1, $\mathrm{S}^{\prime}$ and $\mathrm{S}^{\prime}$ for Dive 2), or shrimps collected with the submersible suction device and subsequently frozen $\left(\mathrm{S}_{\mathrm{T}}\right)$, or shrimps subsequently placed in pressurised aquaria, either for a $10^{\circ} \mathrm{C}$ control $\left(\mathrm{S}_{10}\right)$ or for a $30^{\circ} \mathrm{C}\left(\mathrm{S}_{30}\right)$ or $2^{\circ} \mathrm{C}$ exposure $\left(\mathrm{S}_{2}\right)$ experiment. cDNAs were pooled from 5 shrimps for $\mathrm{S}_{1} \mathrm{~S}^{\prime}, \mathrm{S}^{\prime \prime}$ and $\mathrm{S}_{2}(\mathrm{n}=5)$ experimental conditions, and from 2 independent batches of 5 shrimps for $\mathrm{S}_{10}$ and $\mathrm{S}_{30}(\mathrm{n}=10)$. Four reference genes were selected for the analysis, and specific primers were
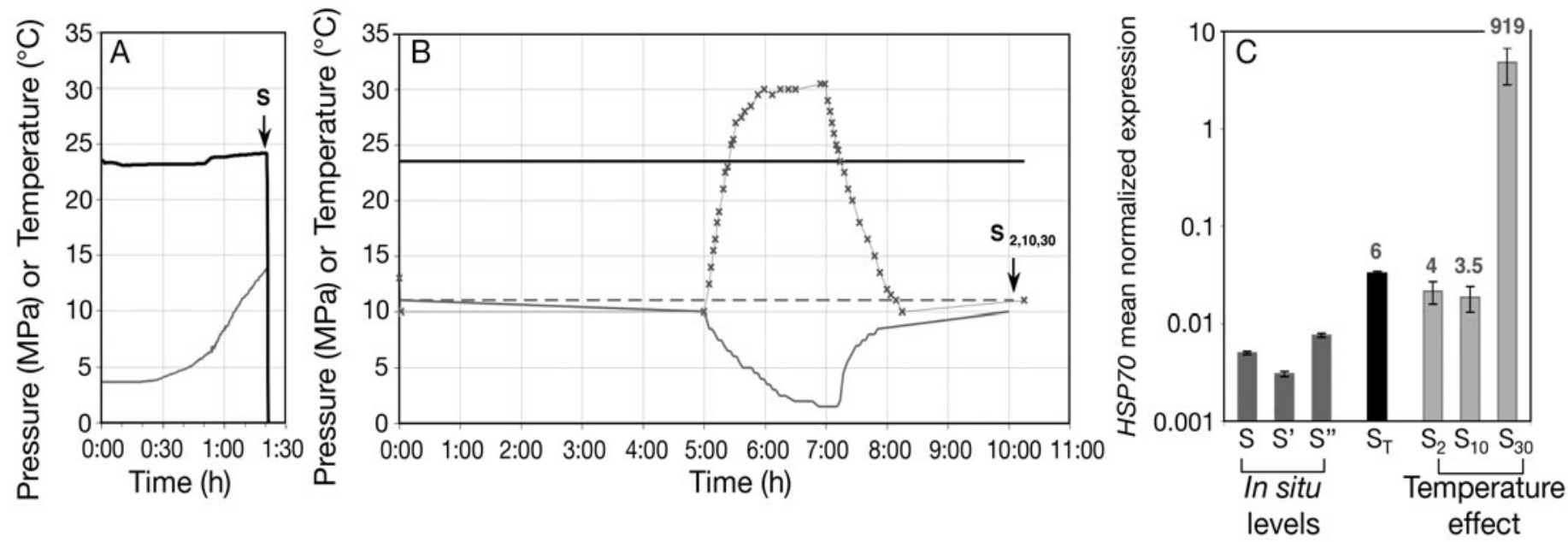

Fig. 1. (A) Pressure (black line) and temperature (grey line) inside the PERISCOP device after sampling of shrimps and subsequent recovery (S) from $2300 \mathrm{~m}$ depth, as a function of time after release from the bottom. Pressure remained constant throughout the ascent, while temperature increased to $14^{\circ} \mathrm{C}$. (B) Pressure (black line) and temperature (grey lines) for in vivo experiments in pressurised aquaria maintained at $10^{\circ} \mathrm{C}$ constant temperature $\left(\mathrm{S}_{10}\right.$; dashed line), or $10^{\circ} \mathrm{C}$ except for $1 \mathrm{~h}$ exposure at $30^{\circ} \mathrm{C}\left(\mathrm{S}_{30}\right.$ i line with crosses) or $2^{\circ} \mathrm{C}\left(\mathrm{S}_{2}\right.$; solid grey line). Arrows in (A,B): time at which the shrimps were frozen until further analyses. (C) hsp70 stress gene expression levels (by qPCR) in shrimps recovered at their native pressure $(\mathrm{S})$, or decompressed $\left(\mathrm{S}_{\mathrm{T}}\right)$, or decompressed and subsequently placed in pressurised aquaria, either for a $10^{\circ} \mathrm{C}$ control $\left(\mathrm{S}_{10}\right)$, or for a $30^{\circ} \mathrm{C}\left(\mathrm{S}_{30}\right)$ or $2^{\circ} \mathrm{C}$ exposure $\left(\mathrm{S}_{2}\right)$ experiment. Two additional assays ( $\mathrm{S}^{\prime}$ and $\mathrm{S}^{\prime \prime}$ ) on shrimp collected during another dive gave equivalent results for $\mathrm{S}$. Values for $\mathrm{S}_{1} \mathrm{~S}^{\prime}, \mathrm{S}^{\prime \prime}, \mathrm{S}_{\mathrm{T}}$ and $S_{2}\left(n=5\right.$ ind.) correspond to a triplicate mean value; values for $S_{10}$ and $S_{30}(n=10$ ind.) correspond to the mean of 2 triplicates. Error bars: \pm SD, numbers above the bars indicate the relative hsp 70 expression with respect to the mean of $\mathrm{S}_{1} \mathrm{~S}^{\prime}$ and $\mathrm{S}^{\prime \prime}$ values 

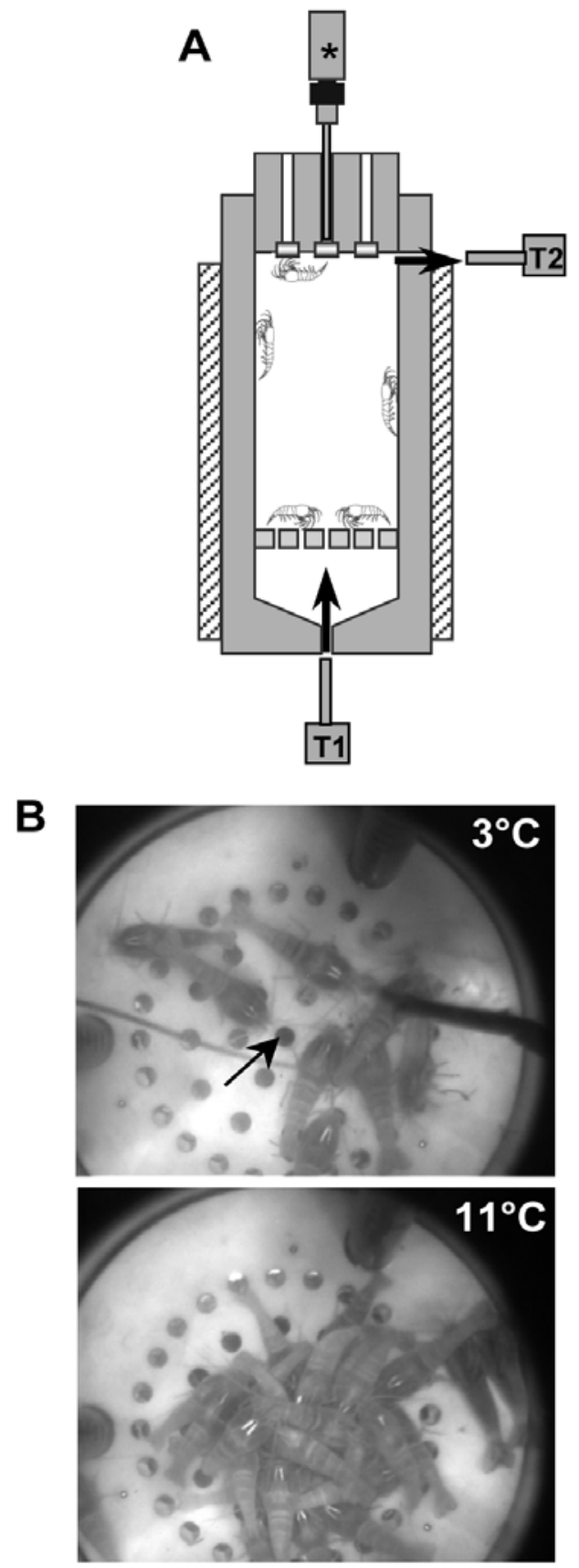

Fig. 2. Rimicaris exoculata. (A) Aquarium set-up. Pressurised vessel (internal diameter $=20 \mathrm{~cm}$, height $=60 \mathrm{~cm}$ ), with 4 sapphire view ports in the lid allowing endoscopic $\left({ }^{*}\right)$ behavioural observations. Arrows indicate inlet and outlet of circulating seawater. Two probes measure the upstream (T1) and downstream (T2) flow temperatures $\left( \pm 1^{\circ} \mathrm{C}\right)$. Temperature is controlled by circulating heat-exchanging fluid around both the pressure chamber (hatched zones) and the seawater inlet line. (B) View of the bottom plate of the aquarium when injecting water at $3^{\circ} \mathrm{C}\left(\mathrm{T} 1 ; \mathrm{T} 2=3^{\circ} \mathrm{C}\right)$ or $11^{\circ} \mathrm{C}(\mathrm{T} 1 ; \mathrm{T} 2=$ $6^{\circ} \mathrm{C}$ ). Of 30 shrimps, 8 are visible at $3^{\circ} \mathrm{C}$ (and 2 close to the view port, showing 1 antenna and 1 leg), and 27 at $11^{\circ} \mathrm{C}$ (24 forming a swarm around the water entrance, 3 on the sides). Arrow in (B) points to the water flow entrance. Length of shrimps $=\sim 5 \mathrm{~cm}$ designed from sequences in GenBank: $\beta$-actin FJ410324, GAPDH FJ875278, RpL8 FJ875277, and 18S gene AM087652. For the hsp70 gene, specific primers were designed from the Rimicaris exoculata hsp70 form1 (DQ534065; Table 1). Each reaction of qPCR was run in triplicate and corresponded to a pool of 5 individuals. All reactions were performed on the iCycler iQ Multicolor Real-Time PCR detection system (BioRad), using Absolute Blue SYBR Green Fluor (Thermo Scientific). The PCR program consisted of an initial 13.5 min step at $95^{\circ} \mathrm{C}$, followed by 45 cycles consisting of $30 \mathrm{~s}$ of denaturation at $94^{\circ} \mathrm{C}, 30 \mathrm{~s}$ of annealing at the optimal annealing temperature $\left(56^{\circ} \mathrm{C}\right)$ and $30 \mathrm{~s}$ at $72^{\circ} \mathrm{C}$. The measurement of fluorescence during the 70 to $95^{\circ} \mathrm{C}$ melting curve showed a single and discrete peak for all primers tested. One negative control and one 5-fold dilution series protocol of pooled cDNA were included in each run. The dilution series were used to construct a relative standard curve to determine the PCR efficiencies and for further quantification analysis. In all experiments, all primers gave amplification efficiencies of 90 to $100 \%$. Data were analysed with the iCycler software (Bio-Rad), the geNorm, Normfinder, and BestKeeper programs. Using the algorithms, the RpL8 gene can be considered as displaying consistent expression and is suitable for downstream analysis. The hsp70 expression was subsequently normalised to this reference and calculated with the Q-Gene software.

\section{RESULTS AND DISCUSSION}

All Rimicaris exoculata specimens recovered from $2300 \mathrm{~m}$ depth without decompression survived the collection process, and were actively swimming inside the pressurised device upon their arrival on the ship deck. The specimens were frozen in liquid nitrogen within seconds after decompression in order to preserve their

Table 1. Primers sequences (F: forward; R: reverse) used for the real-time PCR analyses

\begin{tabular}{|c|c|}
\hline Primer & Sequences $\left(5^{\prime}-3^{\prime}\right)$ \\
\hline GAPDH & $\begin{array}{l}\text { F- CCCCTTCATTGCTCTGGACTAC } \\
\text { R- ACCACCTTGGAAGTGAGCAGA }\end{array}$ \\
\hline RpL8 & $\begin{array}{l}\text { F- GAAGCTCCCATCAGGTGCCAAGAA } \\
\text { R- TTGTTACCACCACCGTGAGGATGC }\end{array}$ \\
\hline B-actin & $\begin{array}{l}\text { F- ACCAGTGCTGAACGTGAGATCG } \\
\text { R- TCTCGTGGACACCAGCAGATTC }\end{array}$ \\
\hline $18 \mathrm{~S}$ & $\begin{array}{l}\text { F- GCTGTGGATTGTAGGCCATGCGCCTAC } \\
\text { R- GGCTGCTGGCACCAGACTTGCCCTCCAA }\end{array}$ \\
\hline Hsp70 & $\begin{array}{l}\text { F- TAAGGACAATATGAAGCAGCAGC } \\
\text { R- TAGCGGGTGGCTCCACAAGGATT }\end{array}$ \\
\hline
\end{tabular}


natural physiological state. We subsequently quantified the level of expression of the heat-inducible $h s p 70$ gene through quantitative real-time PCR (Fig. 1C). To provide a comparison point for natural stress gene levels, we also measured the level of $h s p 70$ expression of $R$. exoculata following experimental temperature shocks $\left(30^{\circ} \mathrm{C}\right.$ or $\left.2^{\circ} \mathrm{C}, 1 \mathrm{~h}\right)$. When compared to the shrimps maintained at constant $10^{\circ} \mathrm{C}$, the $2^{\circ} \mathrm{C}$ exposure had no effect on the stress gene expression, while the $30^{\circ} \mathrm{C}$ exposure boosted the expression of $h s p 70$, which was upregulated 261 -fold in the stressed shrimps. The hsp70 gene is therefore a powerful indicator of heat stress. The 3 batches of shrimps recovered at their in situ pressure showed comparably very low levels of hsp 70, i.e. 919-fold less than in heat-exposed animals, 3.5 -fold less than in $10^{\circ} \mathrm{C}$ control animals and 4 -fold less than in cold-exposed animals (Fig. 1C). This means that these shrimps had not experienced heat stress during the hours that preceded the collection. Since these specimens did not suffer from the usual collection trauma, which was shown to induce a 6 -fold over-expression of $h s p 70\left(\mathrm{~S}_{\mathrm{T}}\right.$ Fig. 1C), these low hsp70 levels were therefore considered as natural levels.

From these results, we can assume that the shrimps are rarely or not exposed in their environment to temperature shocks capable of inducing a molecular response. This assumption is consistent with the shrimp's peculiar 'thermal vision' (Van Dover et al. 1989), which allows it to detect bursts of hot fluid at a distance, before body temperature levels become stressful. Moreover, we provide the first experimental evidence that the shrimps can sense temperature variations of relatively moderate amplitude on a scale of tens of $\mathrm{cm}$. We observed the behaviour of the shrimps maintained in the pressurised aquaria at the temperature of the abyssal water (about $2^{\circ} \mathrm{C}$ for $1 \mathrm{~h}$, Fig. 1B). In this cold water, the animals crawled slowly over all the aquarium surfaces (bottom, vertical wall and lid; Fig. 2B). When increasing the temperature of the entrance flow to $11^{\circ} \mathrm{C}$, the shrimps rapidly swarmed close to the water emission $(60 \%$ of the shrimps aggregated on the hole within $10 \mathrm{~min}$, and at least $80 \%$ a few minutes later; Fig. 2B). This aggregation behaviour is the typical behaviour observed in situ for Rimicaris exoculata, which means that temperature is a major stimulus that attracts this species to the chimney walls. $R$. exoculata would therefore form swarms close to the fluid emission according to its thermal preference. From our in vivo data, we propose the $R$. exoculata thermal preferendum as 10 to $25^{\circ} \mathrm{C}$, since the shrimps seem to avoid temperatures above $24^{\circ} \mathrm{C}$ (Ravaux et al. 2003), and were attracted to water at $11^{\circ} \mathrm{C}$. This is supported by recent temperature measurements in the shrimp swarms at the sampling site ( 3 to $25^{\circ} \mathrm{C}_{i}$ Schmidt et al. 2008). R. exoculata is thus able to choose a very narrow thermal zone where the water temperature is not stressful; finding this zone is a great challenge for a species colonising the leaky surface of black smoker walls.

Our results bridge the gap between temperature exposure in a natural environment and the molecular response, providing the first evidence that vent shrimps are not stressed by heat in their natural environment. We propose that Rimicaris exoculata face the stressful thermal conditions through microhabitat selection and plastic responses to occasional thermal extremes, as opposed to the less mobile alvinellid vent worms, which appear to have shifted their thermal preferendum towards higher temperatures, since these species are assumed to live above $40^{\circ} \mathrm{C}$ (Girguis $\&$ Lee 2006). The involvement of heat-inducible stress responses remains to be seen in such fauna. Future studies using a combination of pressurised technologies and molecular methods will help to address the specific mechanisms underlying metazoan life at high temperature and pressure.

Acknowledgements. This research was funded by the European Community program EXOCET/D. We thank the captain and crew of the RV 'Pourquoi Pas ?'; the DSV 'Nautile' and ROV 'Victor 6000' groups (Ifremer); J. Dyment and F. Gaill (chief scientists of the 'Momardream' 2007 cruise); N. Léger, J. Y. Toullec and M. Zbinden for their technical assistance.

\section{LITERATURE CITED}

Cary SC, Shank T, Stein J (1998) Worms bask in extreme temperatures. Nature 391:545-546

Chevaldonné P, Fisher CR, Childress JJ, Desbruyères D, Jollivet D, Zal F, Toulmond A (2000) Thermotolerance and the 'Pompeii worms'. Mar Ecol Prog Ser 208:293-295

Feder ME, Hofmann GE (1999) Heat shock proteins, molecular chaperones, and the stress response: evolutionary and ecological physiology. Annu Rev Physiol 61:243-282

Girguis PR, Lee RW (2006) Thermal preference and tolerance of alvinellids. Science 312:231

Ravaux J, Gaill F, Le Bris N, Sarradin PM, Jollivet D, Shillito B (2003) Heat-shock response and temperature resistance in the deep-sea vent shrimp Rimicaris exoculata. J Exp Biol 206:2345-2354

Schmidt C, Le Bris N, Gaill F (2008) Interactions of deep-sea vent invertebrates with their environment: the case of Rimicaris exoculata. J Shellfish Res 27:79-90

Shillito B, Hamel G, Duchi C, Cottin D and others (2008) Live capture of megafauna from $2300 \mathrm{~m}$ depth, using a newly designed Pressurized Recovery Device. Deep-Sea Res I 55:881-889

Van Dover CL, Lutz RA (2004) Experimental ecology at deepsea hydrothermal vents: a perspective. J Exp Mar Biol Ecol 300:273-307

Van Dover CL, Szuts EZ, Chamberlain SC, Cann JR (1989) A novel eye in 'eyeless' shrimp from hydrothermal vents of the Mid-Atlantic ridge. Nature 337:458-460

Submitted: June 3, 2009; Accepted: August 31, 2009

Proofs received from author(s): November 18, 2009 